\title{
The Application of Mineral Sorbents to Remove Volatile Organic Compounds from the Gases Emitted from the Composting Processes
}

\author{
Monika Wierzbińska' \\ 1 Department of Environmental Protection and Engineering, University of Bielsko-Biala, Poland \\ e-mail: mwierzbinska@ath.bielsko.pl
}

\begin{abstract}
The disposal of organic waste in processes such as composting is related to the emission of malodorous compounds. Owing to their character and low odour detection threshold, there is often a need for a hundred percent elimination of the contaminants from waste gases. One of alternative methods of treating the waste gases from malodorous contaminants, occurring in low concentrations in post-process air, is the biofiltration method. Most often, the method uses an organic filtration material. However, this method of air purification is still developing; therefore, there is a search for new sorbents among mineral materials, which would be an alternative for organic sorbents. The article presents the research into the application of aluminosilicate sorbents, including halloysite, for deodorization of the gases emitted from the processes of composting municipal waste. The semitechnical scale research was conducted for several weeks in a municipal waste composting plant, passing real gases through two biofilters filled with mineral sorbents. In spite of the fact that some problems occurred and the research cycle was not completed, the experiment proved that halloysite removes odours to a much higher extent than the other examined aluminosilicate sorbent. While the VOCs reduction on a bed with halloysite was $88 \%$, the reduction on a bed with a second aluminosilicate reached $35 \%$. The process conditions were very unstable; therefore, the efficiency of the VOCs removal process varied widely. However, halloysite has always been a better sorbent than the other aluminosilicate.
\end{abstract}

Keywords: Halloysite, odours, composting, biofiltration, aluminosilicates, mineral sorbents

\section{INTRODUCTION}

The neutralization of organic waste in processes such as composting is related to the emission of malodorous compounds [Sówka et al. 2014].They include not only the compounds comprised in waste but also biogenic odorants, forming during the first stage of composting and putrefaction (ammonia, hydrogen sulphide, skatole, mercaptans), substances specific for the composting process (aldehydes, geosmin, limonene), transitional substances forming in the process of anaerobic-aerobic transformations (organic acids), forming in pyrolysis and auto-oxidation [Sówka et al. 2014, Frederickson et al. 2013, KwarciakKozłowska and Bańka 2014]. The emission of $\mathrm{H}_{2} \mathrm{~S}$ or mercaptans can be relatively easily reduced by conducting the process in a proper way (aeration, shovelling heaps). However, there is no possibility to prevent the formation of organic acids or aldehydes.

Owing to their character and low odour detectio threshold, there is often a need for a hundred percent elimination of the contaminants from waste gases. The problem of odours concerns the whole world. Numerous countries, such as Great Britain, Germany, the Netherlands, the Czech Republic, Denmark, Australia, the US, Canada, Japan, South Korea and New Zealand have already undertaken the measures towards legal regulation of the odour emission problem [Kwarciak-Kozłowska and Bańka 2014]. Therefore, optimum methods of removing the odours from waste gases is being searched for. One of more willingly applied methods is biofiltration.

Biofiltration is one of alternative methods of treating the waste gas from malodorous contaminants with low odour detection threshold, 
occurring in low concentrations in the post-process air. Its advantage, in addition to relatively low investment and operating costs [Miller et al. 2018], is the fact that this process is practically waste-free. It causes real elimination of contaminants, and not only a change in the place or the form of their occurrence, at the same time not generating extra waste. This makes gas biofiltration a method currently preferred all over the world [Wysocka et al. 2019].

The biofiltration process consists in the slow flow of a contaminated gas through the layer of a sorption material inhabited by the microorganisms specially matched to the type of contaminations. In order to maintain high effectiveness of the process, optimum conditions of gas, bed and operating parameters must be kept. Contaminants diffuse to the liquid coat covering the sorbent, so-called bio-layer or bio-film where, by means of microorganisms and their enzymes, they are decomposed to carbon dioxide and water and the substances are discharged into the atmosphere as harmless and non-toxic [Wierzbińska 2006, Wierzbińska and Modzelewski 2015, Wieczorek 2010].

A biofilter consists of the housing and the layer of a filtration material which fills it, and which is inhabited by the microorganisms adapted to the decomposition of a given type of contaminants. The shape of the biofilter may differ depending on the spatial capabilities and the scale of use [Wierzbińska 2017, Marada and Vaverková 2010]. One of key parameters determining the effectiveness of the gas treatment process is the type of the applied bed, that is, the filtration material. Therefore, there is a need to look for various sorption materials to increase the effectiveness of the deodorization process.

The experiment was conducted at the semitechnical scale in the composting plant, under real difficult conditions. An innovative aspect was the use of mineral sorbents to remove VOCs from the gases emitted from the composting processes. There are no literature reports on similar studies; therefore, the results cannot be compared with other researchers.

\section{The infill of biofilters}

A biological bed that is the filtration material a biofilter is filled with, should create best possible conditions for the development of microorganisms in order to obtain the maximally fast biodegradation of contaminants. It should be richly inhabited by microorganisms. The concentration of the filtration material along with operating time should be minimal. The porosity of the bed, that is the size and the arrangement of seeds and the structure of pores must ensure high surface activity during a low drop in gas pressure (a large specific surface area, loose structure, low resistances of gas flow) [Wierzbińska and Modzelewski 2015]. Organic sorbents are successfully applied in gas biofiltration. They include: fertile loosened soil, peaty waste, tree bark compost, straw, wooden waste, municipal waste composts, coir, bark, nut shells, spent mushroom cultivation substrate, wheat straw, natural fibres, compost soil or wood shavings [Wysocka et al. 2019, Kwaśny and Balcerzak 2014, Wierzbińska 2014, Yu et al. 2019, Wierzbińska 2018, Wierzbińska 2010a, Wierzbińska 2010b]. However, new, more efficient sorbents are being looked for. Recently, also such mineral sorbents as: halloysite, zeolites, dolomite, pumice, volcanic lava, shales, activated carbon, mineral wool or anthracite [Nikiema et al. 2009, Nikiema and Heitz 2010, Cebula et al. 2015, Sołtys et al, 2013, Xue and Sun 2018, Beniwal et al. 2018, Jaber et al. 2016, Bohdziewicz et al. 2015, Sakiewicz et al. 2015, Radziemska 2018, Żarczyński et al. 2014, Głuszek et al. 2015, Opaliński et al. 2015, Jana et al. 2015, Radziemska and Mazur 2016, Hermawan et al. 2018] or plastic infills [Aguirre et al. 2018] have been applied.

\section{METHODOLOGY}

The research was conducted at the semitechnical scale in the composting plant, under real conditions, passing malodorous gases through the test installation. The conditions were very difficult, because process parameters were very variable.

The research included the observation and assessment of the odour removal process from the waste gases emitted from a composting plant of municipal waste, with the use of two types of sorbents. Two types of mineral sorbents should be used for the research: halloysite $-\mathrm{H}$ and aluminosilicate $-\mathrm{AS}$ with average granulation of $4-10 \mathrm{~mm}$. The experiment was conducted at the semi-technical scale in the composting plant, under real conditions, passing malodorous gases through the test installation presented in Figure 1. 


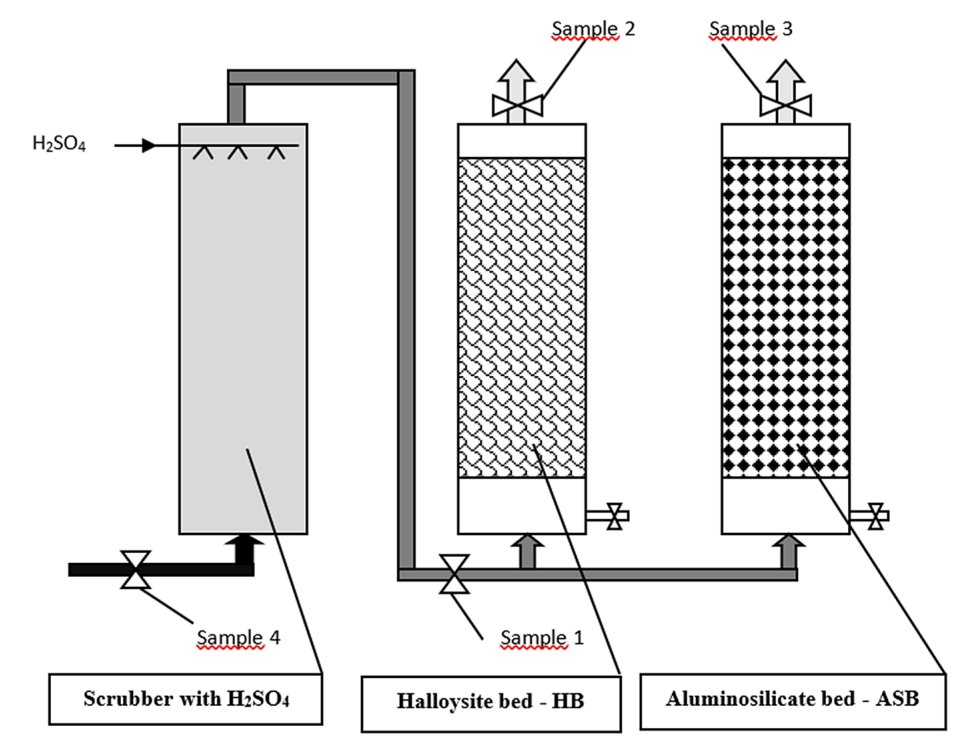

Figure 1. The diagram of an experimental semi-technical installation for gas deodorization with the biofiltration method

The installation consists of two biofilters with the height of $1,500 \mathrm{~mm}$ and the diameter of $270 \mathrm{~mm}$, made of plastic resistant to chemical and thermal factors, closed from the top with tight lids provided with half-inch tubes and stubs for sampling. At the height of $50 \mathrm{~mm}$ from the biofilter bottom stubs are assembled which enable to discharge leachates from beds. Both biofilters were properly filled with sorbents suspended on steel meshes at a height of $200 \mathrm{~mm}$ from the bottom of the biofilters. The height of the beds was $1,150 \mathrm{~mm}$. Each biofilter was provided with measurement stubs on the inlet and the outlet. The gases fed onto the biofilters were first driven onto the scrubber in which, owing to the absorption processes in $\mathrm{H}_{2} \mathrm{SO}_{4}$, the removal of amine compounds took place. Thus, the gases entering the biofilters were pre-treated from ammonia, among others, and moistened. The parameters of the gas flow through the biofilters were set in such a way that the gas retention time in the bed was 50 seconds. Upstream of the biofilters gasometers were installed, in which the meters were read each time during the sample taking.

On the day when the biofilters were filled up, both beds were inoculated up to a height of 10 from the supporting mesh. The microorganisms used were cultivated on halloysite bed, operating before that at the sewage tank in the composting plant.

The preliminary analysis included a few contaminants characteristic for the process of composting, namely ammonia, hydrogen sulphide, methane, mercaptans, amines, volatile organic compounds (VOCs), and acetic acid. The results are presented in Table 1. The gas samples were taken with the methods matching the applied analytical techniques. Ammonia was taken on the filter made of fiberglass impregnated with sulphuric acid, mercaptans on the filter of fibreglass impregnated with mercury acetate, hydrogen sulphide and VOCs into carbon fibre tubes, methane into Tedlar bags, and to separate primary and secondary aliphatic amines silica gel impregnated with $10 \%$ NITC (1-naphthylisothiocyanate) was applied. As there are no studies and emission standards for a composting plant of municipal waste, the analytical method was adjusted to the environmental standards developed by OSHA (Occupational Safety and Health Administration) and NIOSH (National Institute of Occupational Safety and Health). In order to perform markings, the procedures included in the following standards were applied: for ammonia - NIOSH 6015 , for mercaptans - NIOSH 2542, for hydrogen sulphide - NIOSH 6013, for amines - NIOSH 2540 and VOCs - OSHA 07 [Eller and Cassinelli 1994] [Ammonia: Method 6015 1994] [Mercaptans, Methyl-, Ethyl-, And N-Butyl-: Method 2542 1994] [Hydrogen Sulfide: Method 6013 1994] [Diethylenetriamine, Ethylenediamine, Triethylenetetramine: Method 2540 1994].

As VOCs were of the highest concentration of the pollutants subjected to assessment, further examination of the samples was focused on this group of analytes.

The legal basis was PN-Z-04008-7: 2002 / Az1: 2004 Air purity protection - Sampling Principles taking air samples in the work environment and interpreting the results. 
Table 1. The comparison of preliminary measurement results

\begin{tabular}{|l|c|c|c|c|}
\hline \multicolumn{1}{|c|}{ Contaminants } & Sample 1 & Sample 2 & Sample 3 & Sample 4 \\
\hline Ammonia $\left[\mathrm{mg} / \mathrm{m}^{3}\right]$ & $<0.005$ & $<0.005$ & $<0.005$ & $<0.005$ \\
\hline Hydrogen sulphide $\left[\mathrm{mg} / \mathrm{m}^{3}\right]$ & $<0.225$ & $<0.225$ & $<0.225$ & $<0.225$ \\
\hline Methane $[\% \mathrm{v} / \mathrm{v}]$ & 0.01 & 0.1 & $<0.01$ & 0.3 \\
\hline Mercaptans $\left[\mathrm{mg} / \mathrm{m}^{3}\right]$ & $<0.03$ & $<0.03$ & $<0.03$ & $<0.03$ \\
\hline Aliphatic amines $\left[\mathrm{mg} / \mathrm{m}^{3}\right]$ & 0.30 & 0.26 & 0.28 & 0.56 \\
\hline VOCs $\left[\mathrm{mg} / \mathrm{m}^{3}\right]$ & 114.8 & 3.4 & 104.1 & 600.2 \\
\hline Acetic acid $\left[\mathrm{mg} / \mathrm{m}^{3}\right]$ & 0.8 & 20.0 & 24.2 & 2.4 \\
\hline
\end{tabular}

The method involved the adsorption of vapours of volatile organic compounds on activated carbon, desorption with a mixture of $1 \%$ methanol in disulphide carbon and chromatographic analysis (GC / FID) of the obtained solution.

An GC/FID Perkin Elmer AytoSystem XL gas chromatograph with a HP-1 column $(100 \mathrm{~m}$ $\times 0.25 \mathrm{~mm}$ i.d.), coated by a $0.50 \mu \mathrm{m}$ crosslinked methyl siloxane film was utilized for the separation of volatile organic compounds occurring simultaneously in the tested air.

The experimental conditions were as follows: Carrier gas - helium with flow rate $1.5 \mathrm{~cm}^{3} / \mathrm{min}$ Column temperature program:

- initial temperature $40^{\circ} \mathrm{C}$ for $5 \mathrm{~min}$

- temperature rise $5^{\circ} \mathrm{C} / \mathrm{min}$ up to $100^{\circ} \mathrm{C}$

- intermediate temperature $100^{\circ} \mathrm{C}$ held for $5 \mathrm{~min}$

- temperature rise $10^{\circ} \mathrm{C} / \min$ up to $250^{\circ} \mathrm{C}$

- final temperature $250^{\circ} \mathrm{C}$ held for $3 \mathrm{~min}$

Dispenser temperature $250^{\circ} \mathrm{C}$

FID temperature $280^{\circ} \mathrm{C}$

- hydrogen volume stream $40 \mathrm{~cm}^{3} / \mathrm{min}$

- air flow rate $400 \mathrm{~cm}^{3} / \mathrm{min}$

- 100 : 1 sample divider [Makhniashvili and Kowalska 2007].

\section{RESULTS}

The samples are numbered according to the numbers of stub ends presented in Figure 1. Moreover, an analysis was conducted for the presence of aldehydes in sample 4, where the presence of acetaldehyde was proven. The analysis of the acetic acid concentration in the samples was carried out to determine $\mathrm{pH}$.

As it results from Table 1, we mainly deal with the oxygen processes here, which is proven by the lack of hydrogen sulphide and mercaptans and non-quantifiable concentrations of methane. On the other hand, in the studied gas there are amines, organic acids and volatile organic compounds (VOCs) in high concentrations.

The analysis results are presented in the source form (Figures 2-5) and converted into the sampling conditions (Tables 3-7). The samples were taken upstream of the scrubber (sample 4), downstream of the scrubber/upstream of the biofilters (sample 1) and downstream of halloysite biofilter - $\mathrm{H}$ (sample 2) and aluminosilicate biofilter - AS (sample 3).

Table 2 presents the concentrations of aliphatic and aromatic hydrocarbons in the studied samples. The sum of hydrocarbons in the studied samples converted into the amount of the air taken (VOCs) and the conditions of sampling are presented in Tables 3-7.

\section{Analysis of the results}

As it arises from the analysis of the results listed in Table 2, after a one week period of the operation of the experimental installation for the deodorization of waste gases, the concentration of VOCs in the gas after the biofiltration process increased substantially. The concentrations of aliphatic hydrocarbons in the samples taken increased after passing through the $\mathrm{H}$ bed by $70 \%$, and by $140 \%$ after the AS bed. Likewise, after the $\mathrm{H}$ sorbent, the concentrations of aromatic hydrocarbons increased by $93 \%$, and after AS by $220 \%$. Thus, the concentrations of VOCs increased by 1.7 times after $\mathrm{H}$ and 26 times after AS (Figure 2). In that stage, there were no microbiological reactions yet, which were supposed to be the complementation of the deodorization process. It was proven by the lack of $\mathrm{CO}_{2}$ in the exhaust gas, which was not considered in the tables. The total decomposition of organic compounds to $\mathrm{H}_{2} \mathrm{O}$ and $\mathrm{CO}_{2}$ occurs during biological transformations.

After the next few days, the concentrations of VOCs were reduced on both sorbents but on 

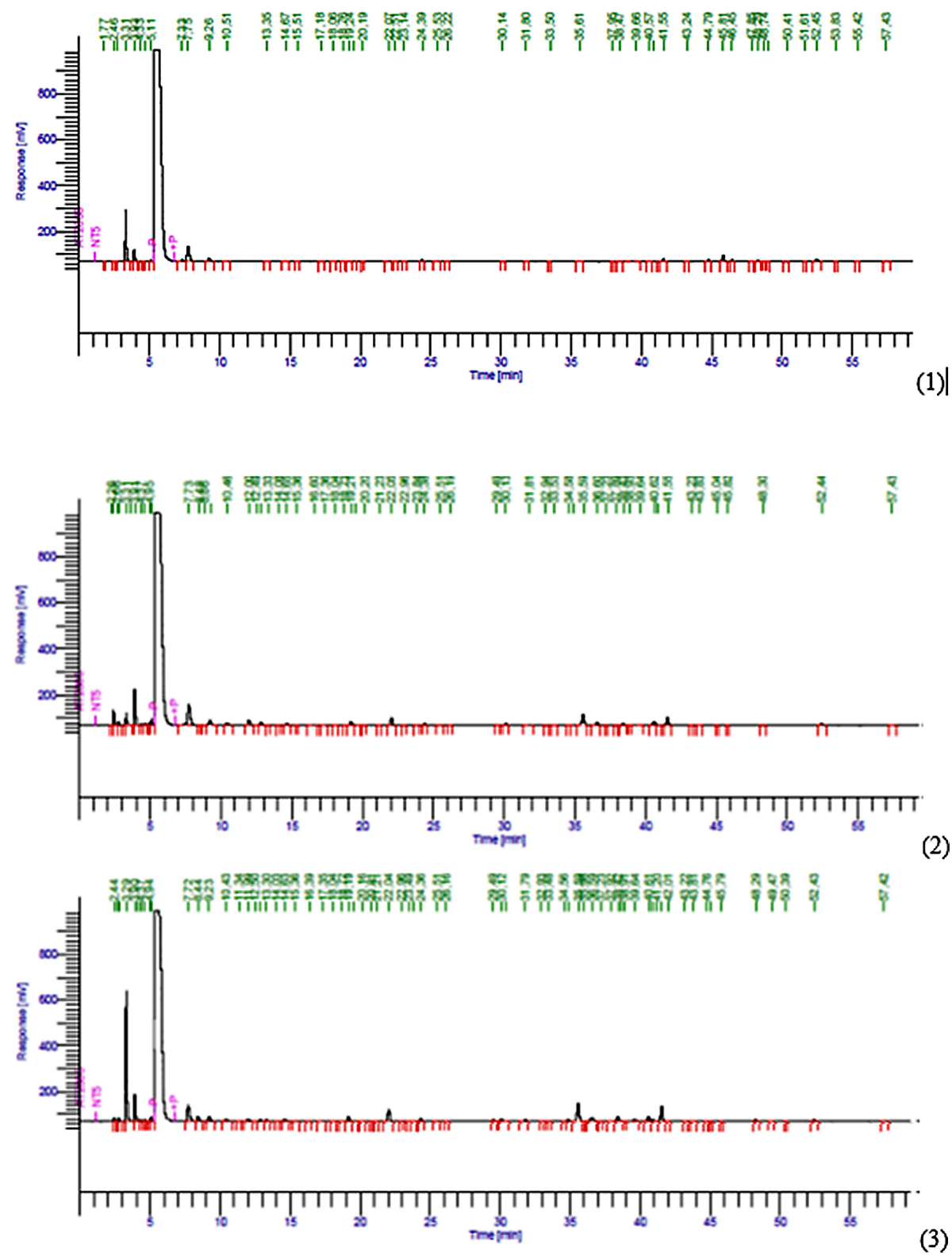

Figure 2. The comparison of chromatograms showing decomposition of VOCs in the industrial gas upstream of the biofilters (1) and downstream of the H biofilter (2) and the AS biofilter ( 3$)\left(1^{\text {st }}\right.$ series)

the outlet of the biofilters, the concentration was lower by $22 \%$ in the case of halloysite and by $15 \%$ in the case of aluminosilicate. In comparison with the concentrations on the inlet to the installation (upstream of the scrubber), the concentrations of VOCs were lower by $91 \%$ and $57 \%$, respectively. The temperature of the gas on the outlet of the installation with the $\mathrm{H}$ bed was $6^{\circ} \mathrm{C}$ lower than downstream of the bed with AS. The $\mathrm{pH}$ was above 6 .

After two weeks of the operation of the research installation at the semi-technical scale, both biofilters started to perform their expected function, but the reduction of contaminants took place to a various extent. The reason for that were very unstable conditions before the installation, that is still before absorption in $\mathrm{H}_{2} \mathrm{SO}_{4}$ (upstream of the scrubber). The concentrations of VOCs downstream of the biofilters, in comparison with concentrations on the installation inlet, dropped by $88 \%$ downstream of the halloysite bed and by 35\% downstream of the bed containing aluminosilicate, but the concentration downstream of the AS sorbent was more than 5 times higher than downstream of the $\mathrm{H}$ sorbent. The $\mathrm{pH}$ of the gas fluctuated around 5.67-5.90, whereas the leachate $\mathrm{pH}$ was above 7. The humidity of the gas downstream of the $\mathrm{H}$ bed was $74 \%$, and downstream of the AS bed, it was $96 \%$ (series III). 


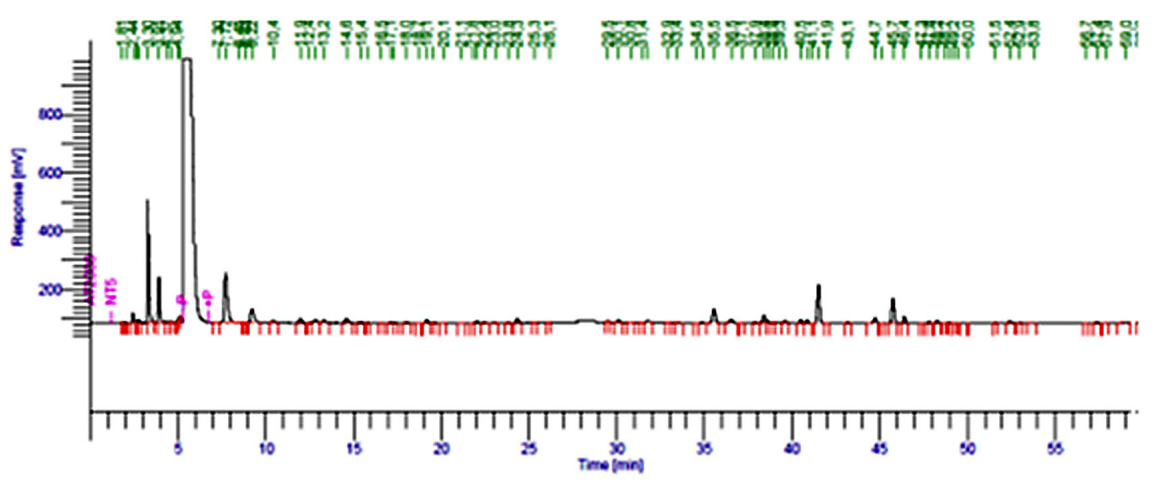

(1)
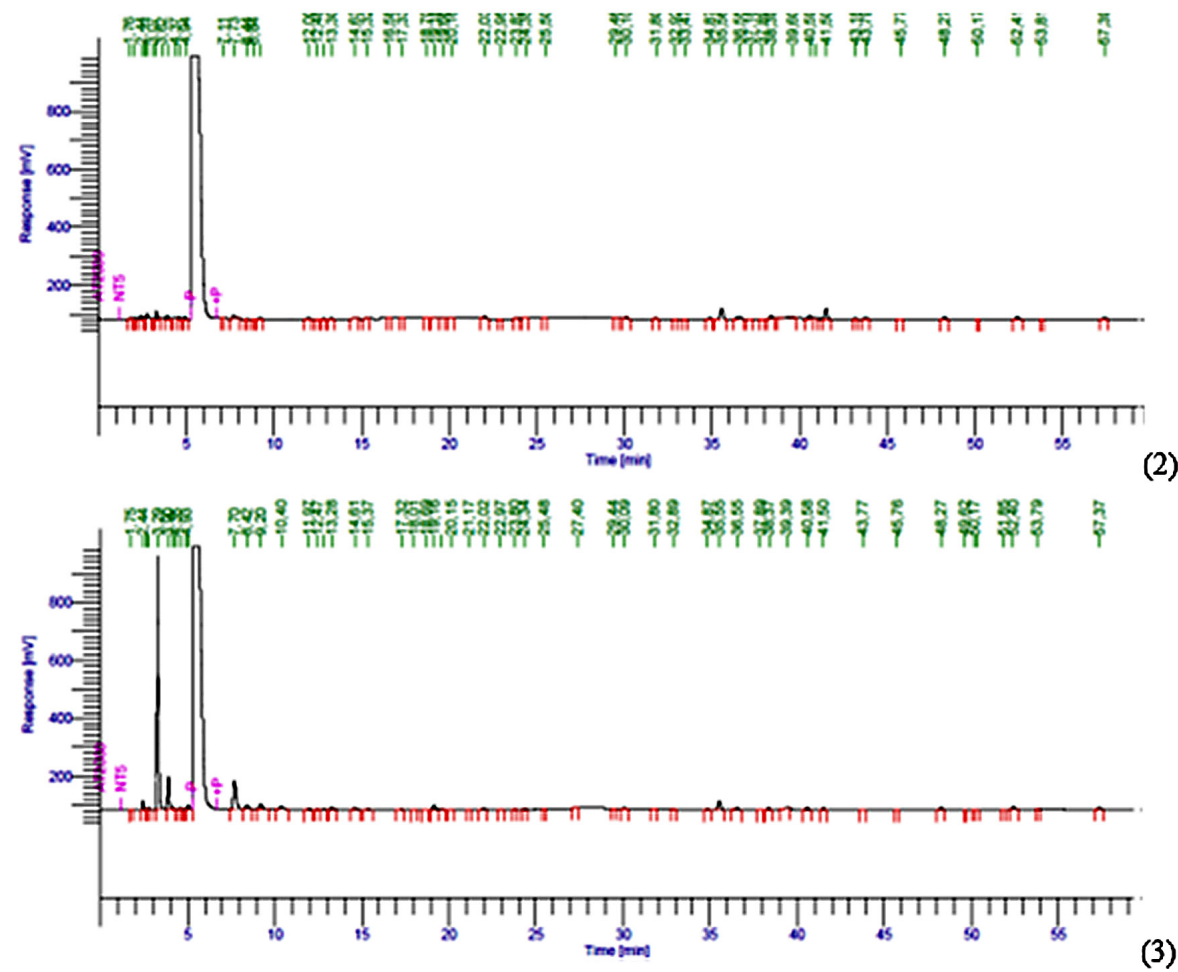

Figure 3. The comparison of chromatograms showing decomposition of VOCs in the industrial gas upstream of the biofilters (1) and downstream of the H biofilter (2) and the AS biofilter (3) (2 ${ }^{\text {nd }}$ series)

After 18 days of research, the level of the removal of VOCs on $\mathrm{H}$ sorbent was $65 \%$, and the concentration of contaminants after deodorization on the AS sorbent increased by $57 \%$ (Figure 4). In comparison with the concentration of VOCs which was examined upstream of the scrubber, it dropped by $26 \%$ downstream of the $\mathrm{H}$ bed, but it increased by $127 \%$ downstream of the AS bed. The temperature of gases on the outlet from the $\mathrm{H}$ bed and the AS bed were similar and amounted to about $23^{\circ} \mathrm{C}$. The humidity of gases downstream of the $\mathrm{H}$ bed was $87 \%$, and downstream of the AS bed it was $90.9 \%$, which would indicate more intensive absorption of humidity by the halloysite sorbent (series IV) (Table 5).
Series V showed an analogous trend. There was a decrease in the concentration of VOCs by $87 \%$ on the $\mathrm{H}$ sorbent and an increase by $24 \%$ on the AS sorbent (Figure 5). The input concentration was more than twice higher than during the previous gas extraction. The $\mathrm{pH}$ of the gas downstream of the beds was relatively low and amounted to 5.92 and 5.64, respectively, with the $\mathrm{pH}$ of the leachate slightly below 7 . The temperature of the gases on the outlet from the installation differed between the beds by almost $6^{\circ} \mathrm{C}$. The humidity of gases was $66 \%$ downstream of the $\mathrm{H}$ bed and $72 \%$ downstream of the AS bed; therefore, it was lower than the required one and probably resulted from the process of water sorption on the sorbents (Table 6). 


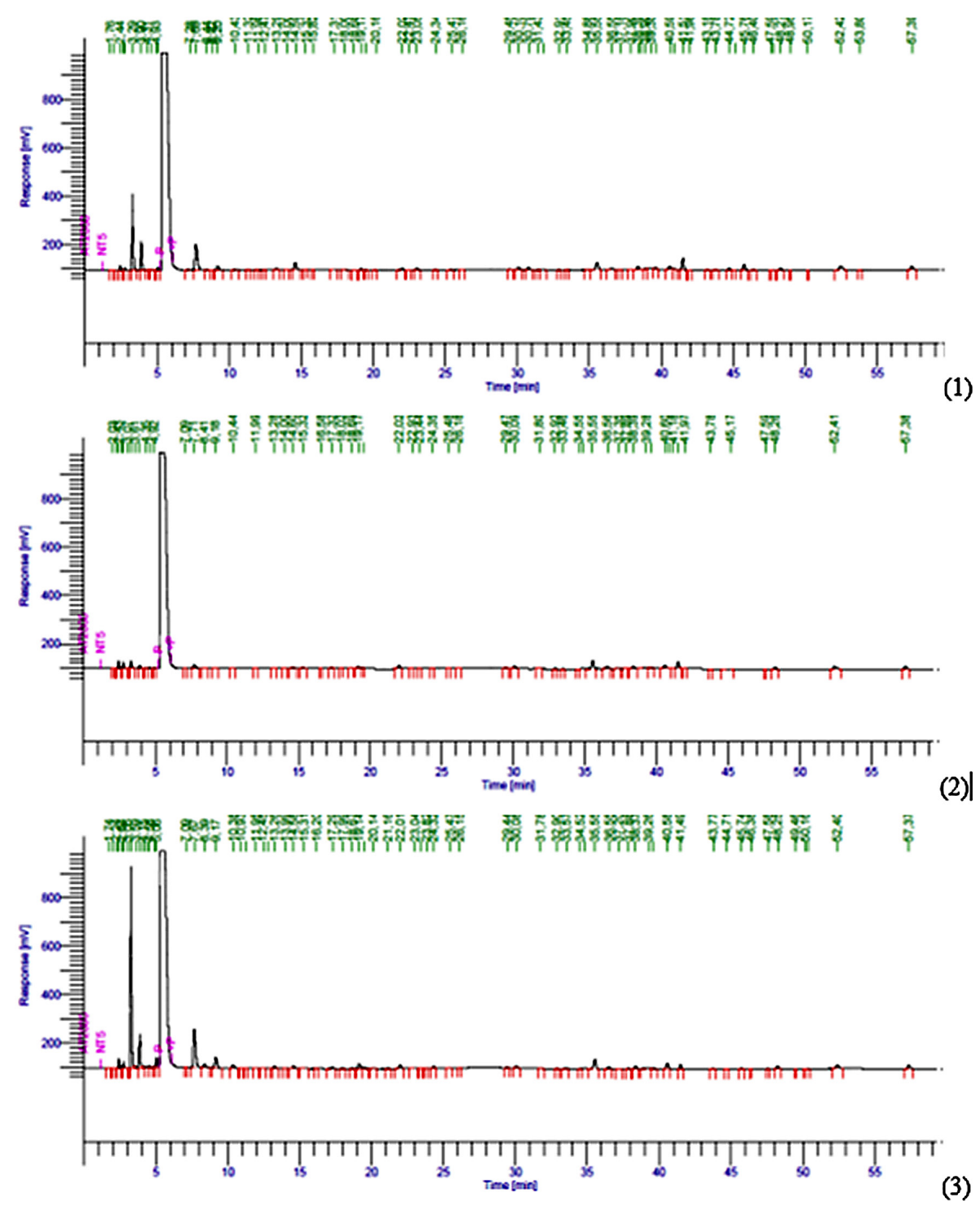

Figure 4. The comparison of chromatograms showing decomposition of VOCs in the industrial gas upstream of the biofilters (1) and downstream of the H biofilter H (2) and the AS biofilter ( 3$)\left(4^{\text {th }}\right.$ series)

After a few days, another analysis of the samples of the air contaminated with Volatile Organic Compounds was conducted. Just like before, halloysite showed better sorption. It reduced the concentrations of organic contaminants by $82 \%$, whereas on the outlet of the gas from the biofilter with the aluminosilicate sorbent, the concentrations increased by $11 \%$. The $\mathrm{pH}$ of the gas and leachate was below 6 , and temperatures of the gas downstream of the $\mathrm{H}$ and AS beds were 28 and $25^{\circ} \mathrm{C}$, respectively. Gas humidity on the outlet of the installation was around $97 \%$ (Table 7).

During the experiment, the temperature of the gas on the outlet from the $\mathrm{H}$ biofilter was in the range of $17-28^{\circ} \mathrm{C}$, whereas downstream of the AS biofilter, it was $23-29^{\circ} \mathrm{C}$ (Tables 3-7). The $\mathrm{pH}$ of the gas downstream of the $\mathrm{H}$ bed changed in the range from 5.55-6.22, and downstream of the AS bed, it was 5.51-6.04 (Tables 3-7). What results from it is that the conditions upstream of the scrubber and the biofilters were very unstable, and the concentrations of odours were changeable, which is proven by the charts presented in Figures 2-5. One can observe that in spite of the fact that both sorbents operated under the same conditions, the $\mathrm{H}$ sorbent performed its function much better. In the majority of cases, it reduced the concentrations of selected odorants, deviating substantially from the AS sorbent. The H sorbent turned out to be a good sorbent for VOCs, and the AS sorbent did not prove to be efficient in removing VOCs from gases. The changeability of VOCs concentrations (the selected results- representative series) is also shown in Figure 6. 


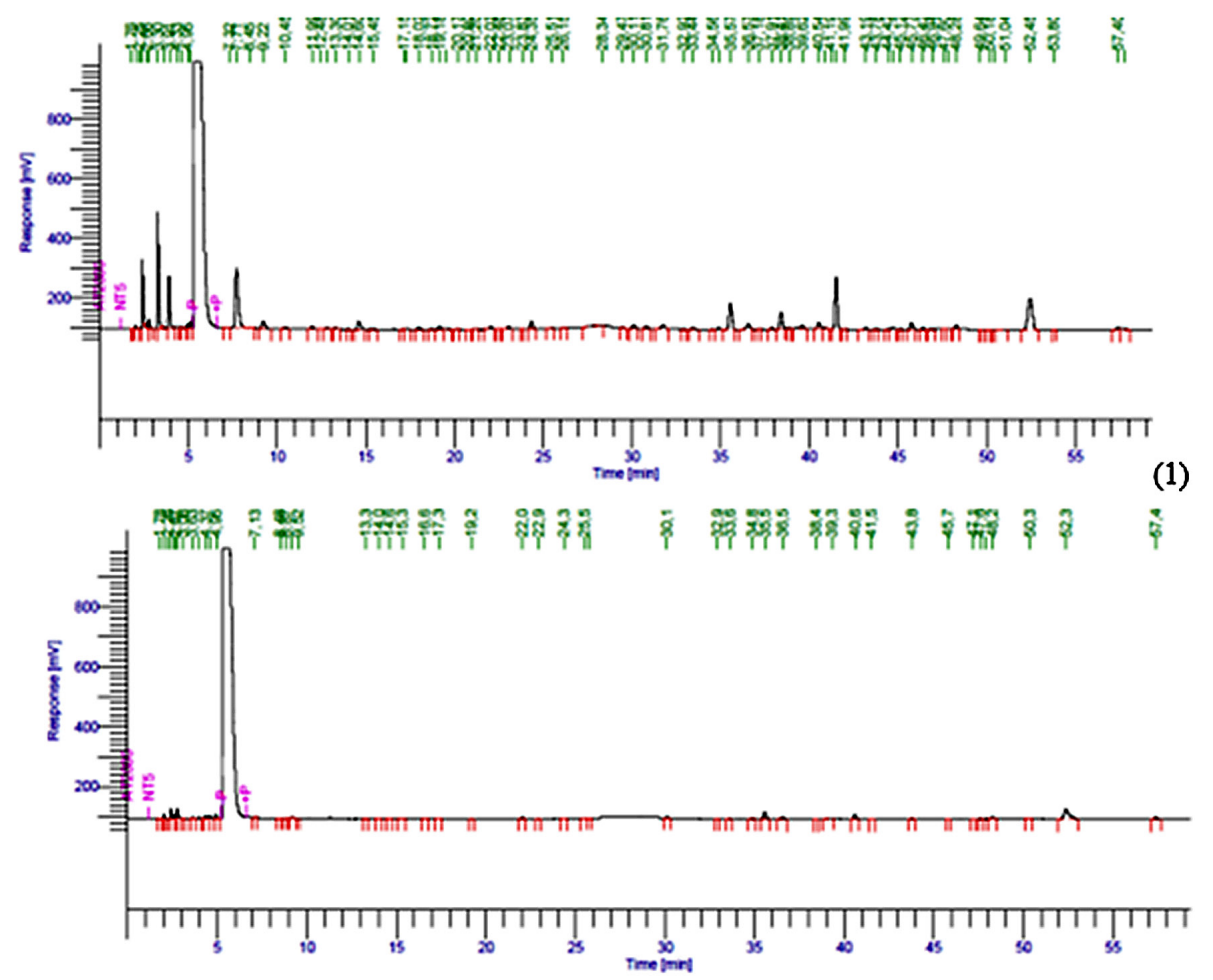

(2)

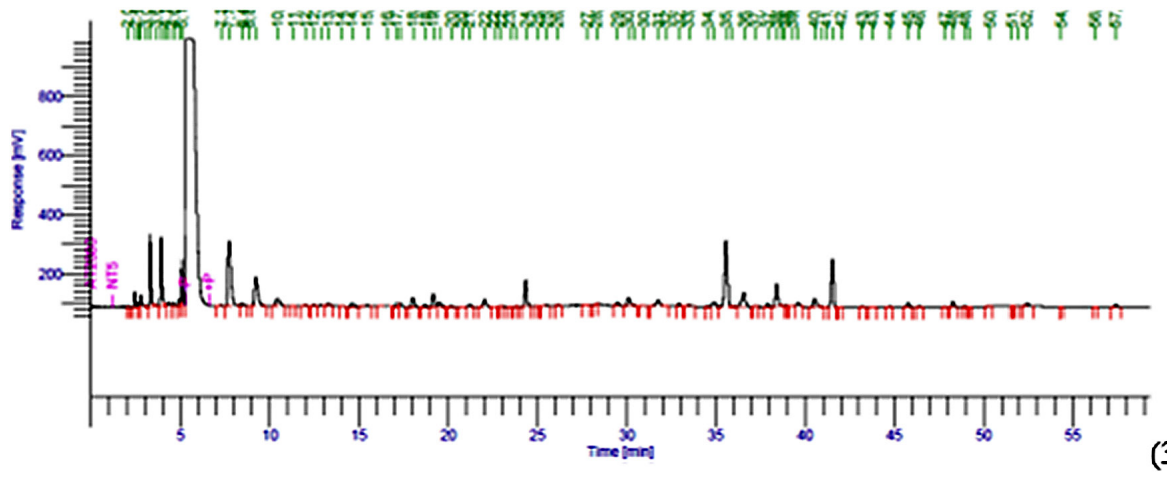

Figure 5. The comparison of chromatograms showing decomposition of VOCs in the industrial gas upstream of biofilters (1) and downstream of the H biofilter (2) and the AS biofilter $(3)\left(5^{\text {th }}\right.$ series)

As the results collected over the few weeks of the research with the use of two mineral biofilters: halloysite and aluminosilicate show, the period was characterised by high instability of the operation of sorbents. It is characteristic for the period of the development of biofilters, when mainly the process of contaminant sorption on the sorption material takes place. After a few weeks from inoculation of the bed, the deodorization process begins to base on the microbiological processes, owing to the organisms which had time to reproduce and settle the whole filtration material during the development of the biofilter. The experiment, however, was interrupted before the process of removing mineral contaminants from the industrial gas stabilized due to the problems which occurred during the operation of the testing biofilters. The most serious was excessive humidity of the gas flowing to the biofilters. There was a malodorous brown liquid flowing to the biofilters from the tubes transporting the process air. Settling on the bottom of the biofilters under the grate on which the bed was suspended, the liquid was an additional source of odours, which disturbed the experiment. It required making siphons enabling to discharge the liquid before entering the reactors. It was also necessary to raise the biofilters to such a height that would allow free drainage of the excess of humidity. Moreover, flooding of bellows gasometers, from which the malodorous brown 
Table 2. The comparison of the concentrations of hydrocarbons in the studied samples

\begin{tabular}{|c|c|c|c|}
\hline \multirow{2}{*}{ Series } & \multirow{2}{*}{ Sample no. } & \multicolumn{2}{|c|}{ Concentration in the sample $[\mu \mathrm{g}]$} \\
\hline & & $\begin{array}{c}\text { Aliphatic } \\
\text { hydrocarbons }\end{array}$ & $\begin{array}{c}\text { Aromatic } \\
\text { hydrocarbons }\end{array}$ \\
\hline & 1 & 421.03 & 92.54 \\
\hline & 2 & 715.68 & 178.64 \\
\hline & 3 & 1039.30 & 294.21 \\
\hline & 4 & 580.25 & 238.83 \\
\hline & 1 & 1090.02 & 381.09 \\
\hline & 2 & 135.70 & 135.08 \\
\hline & 3 & 1161.95 & 91.70 \\
\hline & 4 & 3545.17 & 2228.63 \\
\hline & 1 & 1891.98 & 197.41 \\
\hline & 2 & 157.72 & 116.07 \\
\hline & 3 & 1341.77 & 182.51 \\
\hline & 4 & 1986.03 & 371.87 \\
\hline & 1 & 739.18 & 230.67 \\
\hline & 2 & 186.46 & 161.00 \\
\hline & 3 & 1351.33 & 175.31 \\
\hline & 4 & 324.30 & 141.57 \\
\hline & 1 & 1291.54 & 609.21 \\
\hline & 2 & 133.95 & 120.18 \\
\hline & 3 & 1634.10 & 721.21 \\
\hline & 4 & 3920.82 & 798.12 \\
\hline & 1 & 1173.38 & 529.93 \\
\hline & 2 & 123.28 & 109.37 \\
\hline & 3 & 1729.02 & 618.91 \\
\hline & 4 & 2219.03 & 876.20 \\
\hline
\end{tabular}

liquid was poured out as early as after a week of the operation (Photo 1), has occurred.

An additional difficulty was relatively low pressure of the gas in the cables supplying the gas to biofilters. Initially, it was $300 \mathrm{~Pa}$, decreasing after a week to about $100 \mathrm{~Pa}$, and after two weeks even to $50 \mathrm{~Pa}$. The drop was probably caused by excessive humidity in the bed, where, as a result

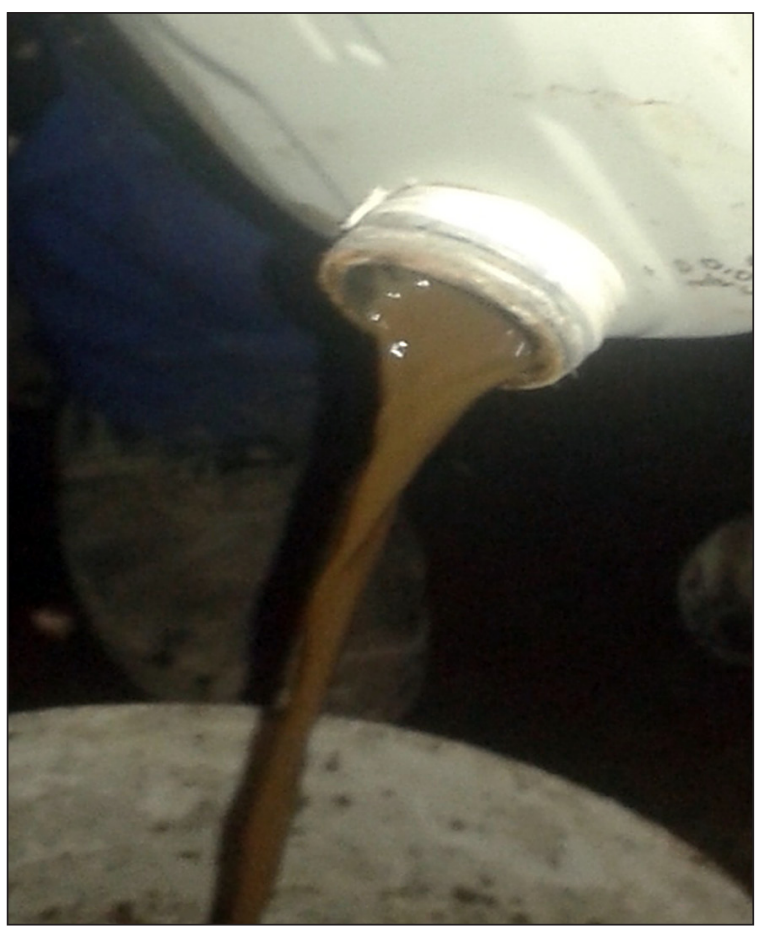

Photo 1. Malodorous liquid poured out of the gasometer

Table 3. The selected results of analyses $-2^{\text {nd }}$ series

\begin{tabular}{|c|c|c|c|c|c|}
\hline & Specification & $\begin{array}{l}\text { Sample no. } 4 \\
\text { upstream of } \\
\text { the scrubber }\end{array}$ & $\begin{array}{l}\text { Sample no. } 1 \\
\text { downstream of the scrubber/ } \\
\text { upstream of biofilters }\end{array}$ & $\begin{array}{c}\text { Sample no. } 2 \\
\text { downstream of } \\
\text { H biofilter }\end{array}$ & $\begin{array}{l}\text { Sample no. } 3 \\
\text { downstream of } \\
\text { AS biofilter }\end{array}$ \\
\hline \multicolumn{2}{|c|}{ VOCs $\left[\mathrm{mg} / \mathrm{m}^{3}\right]$} & 288.69 & 147.11 & 27.08 & 125.37 \\
\hline \multirow{2}{*}{$\mathrm{pH}$} & of gas & 7.16 & 6.40 & 5.55 & 5.92 \\
\hline & of leachate & 7.57 & 6.10 & 6.83 & 6.43 \\
\hline \multicolumn{2}{|c|}{ Temperature $\left[{ }^{\circ} \mathrm{C}\right]$} & - & - & 23.0 & 29.0 \\
\hline
\end{tabular}

Table 4. The selected results of analyses $-3^{\text {rd }}$ series

\begin{tabular}{|l|c|c|c|c|c|}
\hline \multicolumn{2}{|c|}{ Specification } & $\begin{array}{c}\text { Sample no. 4 } \\
\text { upstream of } \\
\text { the scrubber }\end{array}$ & $\begin{array}{c}\text { Sample no. 1 } \\
\text { downstream of the scrubber/ } \\
\text { upstream of biofilters }\end{array}$ & $\begin{array}{c}\text { Sample no. 2 } \\
\text { downstream of } \\
\text { H biofilter }\end{array}$ & $\begin{array}{c}\text { Sample no. 3 } \\
\text { downstream of } \\
\text { AS biofilter }\end{array}$ \\
\hline \multicolumn{2}{|l|}{ VOCs $\left[\mathrm{mg} / \mathrm{m}^{3}\right]$} & 235.79 & 163,03 & 27.38 & 152.43 \\
\hline \multirow{2}{*}{$\mathrm{pH}$} & of gas & 5.80 & 6,73 & 5.67 & 5.90 \\
\cline { 2 - 6 } & of leachate & 8.06 & 6.26 & 7.84 & 7.36 \\
\hline \multicolumn{2}{|l|}{ Temperature $\left[{ }^{\circ} \mathrm{C}\right]$} & - & - & 17.0 & 23.5 \\
\hline Humidity $[\%]$ & - & - & 74.0 & 96.3 \\
\hline
\end{tabular}


Table 5. The selected results of analyses $-4^{\text {th }}$ series

\begin{tabular}{|c|c|c|c|c|c|}
\hline \multicolumn{2}{|c|}{ Specification } & $\begin{array}{c}\text { Sample no. 4 } \\
\text { upstream of } \\
\text { the scrubber }\end{array}$ & $\begin{array}{c}\text { Sample no. 1 } \\
\text { downstream of the scrubber/ } \\
\text { upstream of biofilters }\end{array}$ & $\begin{array}{c}\text { Sample no. 2 } \\
\text { downstream of } \\
\text { H biofilters }\end{array}$ & $\begin{array}{c}\text { Sample no. 3 } \\
\text { downstream of } \\
\text { AS biofilter }\end{array}$ \\
\hline \multicolumn{2}{|l|}{ VOCs $\left[\mathrm{mg} / \mathrm{m}^{3}\right]$} & 460.59 & 96.98 & 34.75 & 152.66 \\
\hline \multirow{2}{*}{$\mathrm{pH} \quad$ of gas } & 5.56 & 5.35 & 6.22 & 6.04 \\
\cline { 2 - 6 } & of leachate & 7.42 & 6.03 & 6.73 & 6.21 \\
\hline \multicolumn{2}{|l|}{ Temperature $\left[{ }^{\circ} \mathrm{C}\right]$} & - & - & 23.4 & 23.8 \\
\hline \multicolumn{2}{l|l}{ Humidity $[\%]$} & - & - & 87.0 & 90.9 \\
\hline
\end{tabular}

Table 6. The selected results of analyses $-5^{\text {th }}$ series

\begin{tabular}{|c|c|c|c|c|c|}
\hline & Specification & $\begin{array}{l}\text { Sample no. } 4 \\
\text { upstream of } \\
\text { the scrubber }\end{array}$ & $\begin{array}{c}\text { Sample no. } 1 \\
\text { downstream of the scrubber/ } \\
\text { upstream of biofilters }\end{array}$ & $\begin{array}{l}\text { Sample no. } 2 \\
\text { downstream of } \\
\text { H biofilter }\end{array}$ & $\begin{array}{l}\text { Sample no. } 3 \\
\text { downstream of } \\
\text { AS biofilter }\end{array}$ \\
\hline \multicolumn{2}{|c|}{ VOCs $\left[\mathrm{mg} / \mathrm{m}^{3}\right]$} & 372.52 & 190.08 & 25.41 & 235.53 \\
\hline \multirow{2}{*}{$\mathrm{pH}$} & of gas & 6.08 & 5.47 & 5.92 & 5.64 \\
\hline & of leachate & 7.79 & 6.42 & 6.81 & 6.67 \\
\hline \multicolumn{2}{|c|}{ Temperature $\left[{ }^{\circ} \mathrm{C}\right]$} & - & - & 17.5 & 23.0 \\
\hline \multicolumn{2}{|c|}{ Humidity [\%] } & - & - & 66.0 & 72.1 \\
\hline
\end{tabular}

Table 7. The selected results of analyses $-6^{\text {th }}$ series

\begin{tabular}{|c|c|c|c|c|c|}
\hline & Specification & $\begin{array}{l}\text { Sample no. } 4 \\
\text { upstream of } \\
\text { the scrubber }\end{array}$ & $\begin{array}{c}\text { Sample no. } 1 \\
\text { downstream of the scrubber/ } \\
\text { upstream of biofilters }\end{array}$ & $\begin{array}{c}\text { Sample no. } 2 \\
\text { downstream of } \\
\mathrm{H} \text { biofilter }\end{array}$ & $\begin{array}{c}\text { Sample no. } 3 \\
\text { downstream of } \\
\text { AS biofilter }\end{array}$ \\
\hline \multicolumn{2}{|c|}{ VOCs $\left[\mathrm{mg} / \mathrm{m}^{3}\right]$} & 222.13 & 174.51 & 31.34 & 193.60 \\
\hline \multirow{2}{*}{$\mathrm{pH}$} & of gas & 6.10 & 5.67 & 5.40 & 5.51 \\
\hline & of leachate & 5.72 & 5.70 & 5.53 & 5.64 \\
\hline \multicolumn{2}{|c|}{ Temperature $\left[{ }^{\circ} \mathrm{C}\right]$} & - & - & 28.3 & 25.0 \\
\hline \multicolumn{2}{|c|}{ Humidity [\%] } & - & - & 97.0 & 97.1 \\
\hline
\end{tabular}

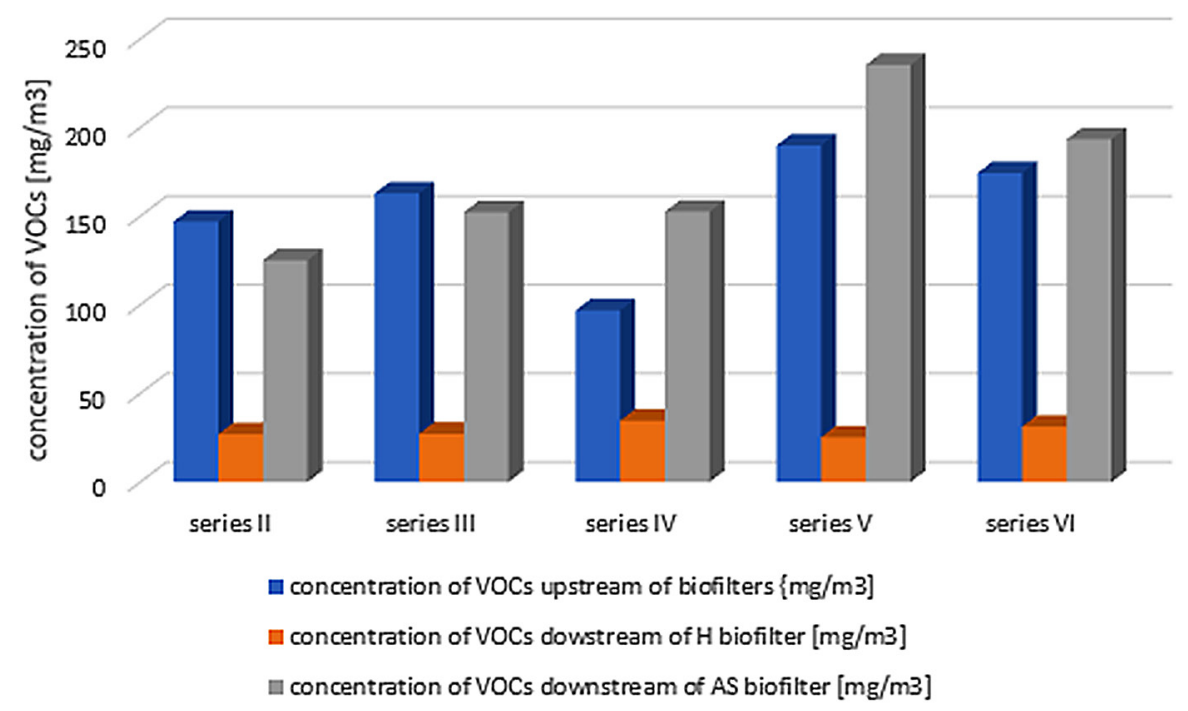

Figure 6. The selected results of changes in the concentrations of VOCs in the industrial gas after passing through the halloysite and aluminosilicate bed 
of the condensation of water vapour, the water filled the pores of the sorbents and resistances of the already insufficient flow increased. Anaerobic zones occurred, where undesired bacterial flora began to develop, probably displacing the aerobic bacteria inoculated during the start of the installation. It would also explain the results of the olfactometric analyses carried out after three weeks of the operation of biofilters, which showed 150000 ou downstream of the $\mathrm{H}$ biofilter, and $300000 \mathrm{ou}$ downstream of the AS biofilter, while upstream of the biofilters the value was $100000 \mathrm{ou}$. It also proves that the dominating source of odours was the fermenting sludge on the bottom of the biofilters. A solution would be to install a pump which would force the flow of gas in the bed, additionally oxygenating the inoculated microflora.

To sum up, it should be noted that in spite of atypical and unstable conditions which took place in the installation while conducting the experiment, the applied sorbents had a tendency to stabilize the efficiency of the deodorization of the gas emitted from the processes of municipal waste composting. It can be assumed that if the conditions had been stable and optimal, both sorbents would prove the high efficiency of odour removal. However, it should be pointed that almost all the obtained results show that halloysite is a better sorbent than aluminosilicate. We do not know if it is also a better medium for the inoculated microflora, because the experiment lasted too short to provide such information.

These results cannot be compared with other researchers, because similar studies have not been described in the literature.

\section{CONCLUSIONS}

1. The experiment planned at the semi-technical scale did not allow determining the overall efficiencies of mineral biofilters due to unstable operating conditions and early termination of the experiment.

2. The halloysite sorbent is a mineral material which is potentially more efficient in biofiltration than the aluminosilicate sorbent.

3. In the first week of the research, when the deodorization process consisted only in the sorption of contaminants on the bed and the damping of sorbents did not take place yet, halloysite eliminated Volatile Organic Compounds in almost $100 \%$.
4. Halloysite proved to be relatively effective in removing VOCs, whereas aluminosilicate did not cope with VOCs at all.

5. In that specific composting plant, the odour problem is created by VOCs, acetaldehyde and acetic acid, whereas such contaminants as: ammonia, hydrogen sulphide, methane and mercaptans can be considered negligible.

\section{REFERENCES}

1. Aguirre A., Bernal P., Maureira D., Ramos N., Vásquez J., Urrutia H., Gentina J.C. \& Aroca G. 2018. Biofiltration of trimethylamine in biotrickling filter inoculated with Aminobacteraminovorans, Electronic Journal of Biotechnology 33, 63-67.

2. Ammonia: Method 6015. 1994. NIOSH Manual of Analytical Methods (NMAM), Fourth Edition, 8/15/94, Issue 2, Page 2 of 7, https://www.cdc.gov/ niosh/docs/2003-154/pdfs/6015.pdf (20.03.2020)

3. Beniwal D., Taylor-Edmonds L., Armour J. \& Andrews R.C. 2018. Ozone/peroxide advanced oxidation in combination with biofiltration for taste and odour control and organics removal, Chemosphere, 212, 272281, https://doi.org/10.1016/j. chemosphere.2018.08.015Get rights and content.

4. Bohdziewicz J., Cebula J., Mrowiec B., Piotrowski K., Prokopenko O., Sakiewicz P. \& Sołtys J. 2015. Application of the halloysite-based sorbent for agricultural biogas purification and elongation of the internal combustion engine life. Scientific Bulletin of the National University of Life and Environmental Sciences of Ukraine. Series: Engineering and Energy of Agro-Industrial Complex, 209, 1, 25-31.

5. Cebula J., Sakiewicz P., Piotrowski K. et al. 2015. The application of multifunctional halloysite-based sorbent halophile for treatment of complex waste gas compounds produced in selected biotechnological processes. II Konferencja Naukowo-Techniczna, Sorbenty mineralne, Surowce, Energetyka, Ochrona Środowiska, Nowoczesne Technologie, Kraków. (in Polish)

6. Diethylenetriamine, Ethylenediamine, Triethylenetetramine: Method 2540. 1994. NIOSH Manual of Analytical Methods (NMAM), Fourth Edition, 8/15/94, Issue 2, Page 2 of 4, https://www.cdc.gov/ niosh/docs/2003-154/pdfs/2540.pdf (20.03.2020)

7. Eller P. M., Cassinelli E. M. 1994. NIOSH, Manual of Analytical Methods 4th edition, U.S. Department of Health and Human Services, Public Health Service, Centers for Disease Control and Prevention, National Institute for Occupational Safety and Health, Division of Physical Sciences and Engineering, Cincinnati, Ohio.

8. Frederickson J., Boardman C.P., Gladding T.L., Simpson A.E., Howell G. \& Sgouridis F. 2013. 
Evidence: Biofilter performance and operation as related to commercial composting. Environment Agency, Bristol.

9. Głuszek M., Antosik A., Żurowski R. \& Szafran M. 2015. Influence of the organic modifiers on properties of halloysite sorbents, Composites Theory and Practice, 15, 2.

10. Hermawan A.A., Chang J.W., Pasbakhsh P., Hart F. \& Talei A. 2018. Applied Clay Science, DOI: 10.1016/j.clay.2017.12.051.

11. Hydrogen Sulfide: Method 6013. 1994. NIOSH Manual of Analytical Methods (NMAM), Fourth Edition, 8/15/94, Issue 1, Page 2 of 4, https:// www.cdc.gov/niosh/docs/2003-154/pdfs/6013.pdf (20.03.2020)

12. Jaber M.B., Couvert A., Amrane A., Rouxel F., Le Cloirec P. \& Dumont E. 2016. Biofiltration of H2S in air-Experimental comparisons of original packing materials and modeling; Biochemical Engineering Journal, 112, 153-160.

13. Jana S., Das S., Ghosh C., Maity A. \& Pradhan M. 2015. Halloysite nanotubes capturing isotope selective atmospheric CO2, Scientific Reports, 5:8711. DOI: $10.1038 /$ srep08711.

14. Kwarciak-Kozłowska A. \& Bańka B. 2014. Biofiltration as a Method of Neutralisation of Odours Produced during Composting the Biodegradable Fraction of Municipal and Industrial Waste, Inżynieria i Ochrona Środowiska, 17(4), 631-645. (in Polish)

15. Kwarciak-Kozłowska A. \& Bańka B. 2014. Biofiltration as a Method of Neutralisation of Odours Produced during Organic Matter Transformation Processes, Inżynieria i Ochrona Środowiska, 17(4), 625-639. (in Polish)

16. Kwaśny J.\& Balcerzak W. 2014. Characteristics of selected indirect methods of reducing the emission of odors; Archiwum Gospodarki Odpadamii Ochrony Środowiska; Archives of Waste Management and Environmental Protection, 16(4), 125-134.

17. Makhniashvili I., Kowalska J. 2007. Lotne związki organiczne-metoda oznaczania, Podstawy i Metody Oceny Środowiska Pracy, 1(51), 141-147.

18. Marada P. \& Vaverková M. 2010. New Construction Solutions of Biofilters Used to Neutralise Malodorous Substances from Technological Gases, Infrastruktura i ekologia terenów wiejskich; Infrastructure and ecology of ruralareas; 8/2/2010, Polish Academy of Sciences, 127-133, Kraków. (in Polish)

19. Mercaptans, Methyl-, Ethyl-, and n-Butyl-: Method 2542. (1994). NIOSH Manual of Analytical Methods (NMAM), Fourth Edition, Issue 1, Page 2 of 4, https://www.cdc.gov/niosh/docs/2003-154/ pdfs/2542.pdf (20.03.2020)

20. Miller U., Sówka I., Grzelka \& A., Pawnuk M. 2018. Application of biological deodorization methods in the aspect of sustainable development, SHS Web of Conferences 57, 02006 https://doi.org/10.1051/ shsconf/20185702006

21. Nikiema J., Girard M., Brzeziński R. \& Heitz M. 2009. Biofiltration of methane using an inorganic filter bed: Influence of inlet load and nitrogen concentration, Canadian Journal of Civil Engineering, 36(12):1903-1910, 10.1139/L09-144.

22. Nikiema J. \& Heitz M. 2010. The use of inorganic packing materials drying methane biofiltration, Hindawi Publishing Corporation International Journal of Chemical Engineering, doi: $10.1155 / 2010 / 573149$

23. Opaliński S., Korczyński M., Szołtysik M., Dobrzański Z. \& Kołacz R. 2015. Application of aluminosilicates for mitigation of ammonia and volatile organic compound emissions from poultry manure, Open Chem, 13, 967-973.

24. Radziemska M. \& Mazur Z. 2016. Content of selected heavy metals in ni-contaminated soil following the application of halloysite and zeolite, Journal of Ecological Engineering, 17(3), .

25. Radziemska M. 2018. Study of applying naturally occurring mineral sorbents of Poland (dolomite, halloysite, chalcedonite) for aided phytostabilization of soil polluted with heavy metals, Catena 163, 123-129.

26. Sołtys J., Schomburg J., Sakiewicz P. et al. 2013. Halloysite from Dunino Deposit as a Raw Material for Mineral Sorbent Production, I Konferencja Naukowo-Techniczna Sorbenty mineralne, Kraków. (in Polish)

27. Sówka I., Miller U. \& Sobczyński P. 2014. Emission of Odours from Municipal Waste Composting Processes, Przemysł Chemiczny, 1, 93(15), 1003-1003. (in Polish)

28. Sakiewicz P., Cebula J., Piotrowski K., Nowosielski R., Wilk, R. \& Nowicki M. 2015. Application of micro- and nanostructural multifunctional halloysite-based sorbents from DUNINO bed in selected biotechnological processes, Journal of Achievements in Materials and Manufacturing Engineering, 69, 2, 69-78.

29. Wieczorek A. 2010. Biofiltration of Waste Gases Contaminated with Volatile Organic Compounds. Technical and Microbiological Aspects, Habilitationdissertation, Szczecin. (in Polish)

30. Wierzbińska M. 2006. The Application of Natural Fibres For Deodoration of Waste Gases, University of Bielsko-Biała, Faculty of Materials, Civil and Environmental Engineering, doctoral dissertation, Bielsko-Biała 2006. (in Polish)

31. Wierzbińska M. 2008. Estimation of the Influence of Sorption Properties of Selected Natural Fibres on the Efficiency of Deodorisation Processes of Industrial Waste-Gases, Fibres and Textiles in Eastern Europe, 16(1), 108-112. 
32. Wierzbińska M. 2010a. The Application of Bioflitration Method For Deodorisation of Waste Gases with the Use of Fibrous Beds. Part 3. The Research into the Effectiveness of Odour Biofiltration with the Use of Beds Being a Mixture of Selected Materials of Natural Origin, Ochrona Powietrza i Problemy Odpadów, 3, 96-107. (in Polish)

33. Wierzbińska M. 2010b. The Application of Bioflitration Method For Deodorisation of Waste Gases with the Use of Fibrous Beds. Part 4. An Analysis of the Efficiency of Biofilters Depending on the Applied Fibrous Bed and the Examination of the Filtration Material After the, Ochrona Powietrza i Problemy Odpadów, 4, 142-154. (in Polish)

34. Wierzbińska M., 2014. Biofiltration of Industrial Waste Gases with the Use of Natural Fibrous Beds, online access 30.05.2014, wis.pol.lublin.pl/kongres3/tom2/29.pdf (in Polish)

35. Wierzbińska M. \& Modzelewski W.E. 2015. The Use of Biofilters for Deodorisation of Malodorous Gases, Ecol. Eng., 41, 125-132. (in Polish)

36. Wierzbińska M. 2017. Biofilters as Structures in
Enviornmental Engineering, Materiały Budowlane, 12, 27-30, Wyd. SIGMA-NOT. (in Polish)

37. Wysocka I., Gębicki J. \& Namieśnik J. 2019. Technologies for deodorization of malodorous gases, Environmental Science and Pollution Research, 26, 9409-9434. https://doi.org/10.1007/ s11356-019-04195-1

38. Xue C. \& Sun X. 2018.Study on Compound Deodorization Experiment of Spray Tower - Biological Filter, 2nd International Workshop on Renewable Energy and Development (IWRED 2018); IOP Conf. Series: Earth and Environmental Science 153, 032041 doi :10.1088/1755-1315/153/3/032041.

39. Yu Y., Hou J., Li M., Meng F., Xi B., Liu D. \& Ye M. 2019. Selection and Optimization of Composting Packing Media for Biofiltration of Mixed Waste Odors, Waste and Biomass Valorization, https://doi. org/10.1007/s12649-019-00744-4.

40. Żarczyński A., Rosiak K., Anielak P. \& Wolf W. 2014. Practical methods of clearing biogas from hydrogen sulphide. Part 1. Application of solid sorbents, Acta Innovations, 12, 24-34. 